\title{
Research on the Time When Ping Split into Yin and Yang in Chinese Northern Dialect
}

\author{
Ma Chuandong $^{1^{*}}$, Tan Lunhua ${ }^{2}$ \\ ${ }^{1}$ College of Fundamental Education, Sichuan Normal University, Chengdu, China \\ ${ }^{2}$ Sichuan Science and Technology University for Employees, Chengdu, China \\ Email: * machuandong2006@163.com
}

Received January $7^{\text {th }}, 2014$; revised February $8^{\text {th }}, 2014$; accepted February $18^{\text {th }}, 2014$

\begin{abstract}
Copyright (C 2014 Ma Chuandong, Tan Lunhua. This is an open access article distributed under the Creative Commons Attribution License, which permits unrestricted use, distribution, and reproduction in any medium, provided the original work is properly cited. In accordance of the Creative Commons Attribution License all Copyrights (C) 2014 are reserved for SCIRP and the owner of the intellectual property Ma Chuandong, Tan Lunhua. All Copyright $@ 2014$ are guarded by law and by SCIRP as a guardian.
\end{abstract}

The phonetic phenomenon “ping split into yin and yang” 平分阴阳 is one of the most important changes of Chinese tones in the early modern Chinese, which is reflected clearly in Zhongyuan Yinyun 中原音韵 by Zhou Deqing 周德清 (1277-1356) in the Yuan Dynasty. The authors of this paper think the phenomenon "ping split into yin and yang" should not have occurred so late as in the Yuan Dynasty, based on previous research results and modern Chinese dialects, making use of historical comparative method and rhyming books. The changes of tones have close relationship with the voiced and voiceless initials in Chinese, and the voiced initials have turned into voiceless in Song Dynasty, so it could not be in the Yuan Dynasty that ping split into yin and yang, but no later than the Song Dynasty.

Keywords: Ping Split into Yin and Yang 平分阴阳; Zhongyuan Yinyun 中原音韵; Voiced Initials Turning into Voiceless (Devoicing); Variants of Tonemes; Historical Comparative Method; Chinese Dialect the Yuan Dynasty; The Song Dynasty

\section{Introduction}

Standard Chinese is a typical tone language in which the pitch contour over a syllable can distinguish word meanings (San Duanmu, 2007). At present, most experts agree, based on the previous studies on the phonology of Chinese, that the tones of Chinese came into being during the period between Zhou Dynasty (through Qin Dynasty) and Han Dynasty, when the ancient Chinese language developed.

Languages change in their development together with other things in the universe. As time goes by, from ancient to present, the changes of Chinese are obvious, especially during the period when the early modern Chinese developed (9AD-1800 $\mathrm{AD})$, as far as the tones are concerned earlier. For example, the qusheng 去声 “falling tone” came into being in Wei and Jin Dynasties; the voiced shangsheng 全浊上声 “falling-rising tone” became qusheng 去声 in the Later Han Dynasty and Five Dynasties; the ping 平 “level” was split into yin ping 阴平 “high level” and yang Ping 阳平 “rising tone” and the loss of the entering tone in Yuan Dynasty, etc. The tones of Northern Chinese have been evolving in the following way, see Table 1.

In this paper, we focus on the question: whether the change of tone, that is, the ping tone split into yin ping and yang ping, occurred in the Yuan Dynasty.

\section{Part I}

We believe that what were recorded in Zhongyuan Yinyun 中 原音韵, similarly hereafter reflects the phonetic phenomena of *Corresponding author. the Yuan Dynasty, but we doubt whether the ping did split into yin and yang in the Yuan Dynasty. Linguists studying Chinese phonology mainly rely on the ancient rhyming books, and they could have written different rhyming books to meet different needs. It is not only possible, but also on record. For example, in the Yuan Dynasty, Chinese opera became one of most important form of literature, and Zhou Deqing 周德清 (12771356) wrote Zhongyuan Yinyun to meet the need of writing words for operas. Compared with the traditional poetic proses, Chinese operas were less formal and more colloquial. In order to shorten the distance between operas and audiences, making it

Table 1.

The evolution of Chinese tones.

\begin{tabular}{ll}
\hline $\begin{array}{l}\text { Ping 平 (level) } \\
\text { shang 上 (falling-rising) } \\
\text { changru 长入 (long entering) }\end{array}$ & $\begin{array}{l}\text { The Pre-Qin period to the Eastern } \\
\text { Han Dynasty }\end{array}$ \\
$\begin{array}{l}\text { Ping 平 } \\
\text { shang 上 }\end{array}$ & \\
qu 去 & The Northern and Southern \\
ru 入 & Dynasties to the Song Dynasty \\
yin ping 阴平 & \\
yang ping 阳平 & \\
shang 上 & The Yuan Dynasty to present \\
qu 入 &
\end{tabular}

Note: (Wang Li, 1985). 
popular among ordinary people, Zhou stressed that the ping split into yin and yang was so important for the words in operas as the heart for a man, therefore, Zhou showed clearly in his book where the words with yin or the words with yang should be used for the tunes to which "qu" "tune in Chinese" was composed. That is why Zhongyuan Yinyun is unique and exact, different from other rhyming books (Yang Naisi, 1981). Zhongyuan Yinyun provides an authentic situation of the oral Chinese in the Yuan Dynasty for linguists who research on Chinese phonology later, and it also contributes a lot for the scientific classification of the the objective phenomenon. But it is not convincing that it was not until the Yuan Dynasty the ping split into yin and yang if we only judge from the materials in Zhongyuan Yinyun.

\section{Part II}

It is well-known that the splitting and integrating of tones have a close relation with the pronunciation of the initial consonants in Chinese. Another factor related with the theme of this paper is the phonetic change in early modern Chinesevoiced consonants turning into voiceless.

Having made further studies on such materials as rhyming books, wordbooks, ancient dictionaries, poems written by the northern literati, Dunhuang bianwen 敦煌变文 (a popular form of narrative literature flourishing in the Tang Dynasty), sino-tibetan transliteration in the Tang Dynasty, and other folk literature, listed in The Northern Speech Sound in Tang Wu Dai 唐五代的北方语音 written by Zhou Zumo 周祖谟, many linguists both at home and abroad have found that the voiced consonants becoming voiceless in the northern Chinese might have started from Tang Wu Dai and finished no later than the time of Shao Yong 郡雍 (1011-1077) (Jiang Shaoyu, 1994). Wang Li 王力 (1985), depending on the materials by Zhu Xi 朱喜 (1130-1200) on fanqie (a traditional method of indicating the pronunciation of a Chinese character) and yeyin (rhyming words in ancient Chinese) found that the devoicing phenomenon appeared in the Song Dynasty. Judging by the living environment of $\mathrm{Zhu} \mathrm{Xi}$, we can conclude that what he reflected in his works "should be the fixed dialect in northern Fujian province” (Li Rulong, 1991), which indicates that the devoicing in both north and south Chinese dialects might happen in more or less the same time. If so, we can rewrite the table of the consonants in the Song Dynasty, as is shown in Table 2.

Compared with the Song Dynasty, as far as the manner of articulation is concerned, the consonant system in the Yuan Dynasty had little changes, remaining the situation: VoicelessSub-Voiceless-Sub-Voiced.

If ping split into yin and yang in the Yuan Dynasty, then, the combination of consonants with the four tones would be like these, see Table 3. (In this paper, we only take the combination of consonants with "Bang" group to save space. To avoid the interference of ru tone, we hereby take yang rhym with Bang group as an example.)

Considering the relevant combinations in modern Chinese, we have a question: where does yang ping for the combination of stop consonants and affricates with yang rhyme in modern Chinese come from? Since the voiced "Bing" consonants converges with voiceless consonants "Bang and Pang", how can it evolve according to its position in the sound system before the convergency?

To answer the second question, let's consider the other phonetic changes. According to Zhen Shangling's 甄尚灵 (1988)
Table 2.

The table of the consonants in the Song Dynasty.

\begin{tabular}{|c|c|c|}
\hline $\begin{array}{l}\text { Voiceless } \\
\text { (全清) }\end{array}$ & $\begin{array}{l}\text { Sub-Voiceless } \\
\text { (次清) }\end{array}$ & $\begin{array}{l}\text { Sub-Voiced } \\
\text { (次浊) }\end{array}$ \\
\hline 帮並风[p] & 滂並平[p'] & 明 $[\mathrm{m}]$ \\
\hline 非敷奉[f] & & 微 $[\mathrm{m}]$ \\
\hline $\begin{array}{l}\text { 精从风[ts] } \\
\text { 心邪 }[\mathrm{s}]\end{array}$ & & 清从平 $\left[\mathrm{ts}^{\mathrm{s}}\right]$ \\
\hline 端定风[t] & 透定平 $\left[\mathrm{t}^{\mathrm{t}}\right]$ & $\begin{array}{c}\text { 泥娘[n] } \\
\text { 来[l] }\end{array}$ \\
\hline $\begin{array}{c}\text { 知澄贝照床视 }[\mathrm{t}] \\
\text { 审禅 }[\mathrm{c}]\end{array}$ & 徹澄平穿床平[ $\left.\mathrm{tc}^{\circ}\right]$ & $\begin{array}{c}\text { 影喻[j] } \\
\text { 日[r] }\end{array}$ \\
\hline $\begin{array}{l}\text { 见群风[k] } \\
\text { 晓匣[h] }\end{array}$ & 溪群平 $\left[\mathrm{k}^{\mathrm{c}}\right]$ & 疑 $[\mathrm{y}]$ \\
\hline
\end{tabular}

Table 3.

The combination of consonants with the four tones in the Yuan Dynasty.

\begin{tabular}{|c|c|c|c|}
\hline Initials & Voiceless & Sub-Voiceless & Sub-Voiced \\
\hline Tone & 帮並么[p] & 滂並平[p'] & 明 $[\mathrm{m}]$ \\
\hline Yin 阴平 & + & + & $\mathrm{O}$ \\
\hline Yang 阳平 & $\mathrm{O}$ & $\mathrm{O}$ & + \\
\hline Shang 上声 & + & + & + \\
\hline $\mathrm{Qu}$ 去声 & + & + & + \\
\hline
\end{tabular}

research, in the late $19^{\text {th }}$ century, in Sichuan dialect sound system described in Xishu Fangyan 西蜀方言 “Western Mandarin or the Spoken Language of West China” by Adam Grainger (1900), [ts] and [ts] were different phonemes, so they distinguished of word meanings, but in the early 1940s, the [ts,ts's] in Chengdu dialect were converged into [ts,ts',s] (Yang Shifeng, 1951). Soon after, from middle 1950s, Chinese government has been spending great effort popularizing Beijing pronunciation as Putonghua 普通话, similarly hereafter) “Common Speech”. But unfortunately, up till now, people in Sichuan dialect area still have great difficulty in distinguishing words with the initial consonants [ts,ts',s] from those with [ts,ts',s] when learning Putonghua. Many people don't know which words should be read as $\left[\mathrm{ts}_{\mathrm{s}}, \mathrm{ts}{ }^{\star}, \mathrm{s}\right]$ and which as $\left[\mathrm{ts}^{\mathrm{t}} \mathrm{ts}{ }^{\prime}, \mathrm{s}\right]$. As a result, in Sichuan dialect area, the confusion of the two group words becomes one of the prominent features when people speak "Putonghua with Sichuan accent” (Wang Wenhu, 1994). In fact, in the late 19 century, the [ts,ts',s] group in Sichuan (Chengdu) sound system came from the same origin with Putonghua (but smaller in scope). In addition, the time when the [ts,ts's $s]$ in Chengdu dialect were converged into [ts,ts',s] was not far from now, and at the same time, the government has spent great effort popularizing Putonghua, it should not be difficult for people in Chengdu to distinguish the words with initial consonant [ts] by rights, but unfortunately it is not satisfactory.

Many phonetic changes indicate that if two or more classes of sound are converged into one, its continual evolution must depend on its position in the sound system. For example, A and $B$ are converged into $C$, then $C$ would evolute on its position in the sound system instead of A's or B's.

Judging by this, we can conclude that it is impossible for the 
words with initial voiced consonant “並[p]”, which had already been converged into voiceless consonant, detached from it and turned into yang ping, if it were true that the ping split into yin and yang in the Yuan Dynasty.

Hsueh (1975) once had a very interesting description on the evolution of the tone in early modern Chinese. He said, "Some tonemes in ancient Chinese phonology might have two or more variants," "when voiced consonants had become voiceless, the variants covered up before became dominant and the redundant feature became the distinguishing one.” Thus, "The splitting and reorganization of the tones in ancient Chinese phonology occurred earlier than the time of devoicing."

Based on the systematicness of sounds and phonetic evolution regularity, we suppose that before the devoicing, both the voiced and voiceless initials had experienced the phonetic evolution of splitting, then we may have the following combination, see Table 4.

Then "voiced initials becomes voiceless", yang ping of “並” fills up the slot of the yang ping of “滂[p"]", which is in accordance with the combination in modern Beijing dialect, see Table 5 (Xu Tongqiang, 1991).

\section{Part III}

Modern linguists hold the idea that the evolution of language can be presented both in time and space. In fact, ancient Chinese scholars had long have brilliant exposition to it. In the Min Dynasty, Chen Di once said, "Within a group, people speak differently because they live in different places; in one hundred years, language changes gradually because of the change of time” (Dushi Zhuoyan, Ming D.). And he also said, “Time differs as there are ancient and modern, places differ as there are the north and the south, words and sounds differ as time goes by, which is the general trend of history" (Author's Preface to Maoshi Guyin Kao). Unfortunately, this valuable theoretical knowledge failed to play its role in guiding the practice of the ancient phonology research. They did not realize the inner relationship between time and space, as a result, the ancient phonology research appeared a halt when it reached the peak in the Qing Dynasty.

In fact, the synchronic differences of dialects resulted from

Table 4.

The combination of bilabial consonants with yin and yang.

\begin{tabular}{ccccc}
\hline & 帮[p] & 浐[p`] & 並[b] & 明 $[\mathrm{m}]$ \\
\hline Yin 阴平 & + & + & $\mathrm{O}$ & $\bigcirc$ \\
Yang 阳平 & $\mathrm{O}$ & $\mathrm{O}$ & + & + \\
\hline
\end{tabular}

Table 5.

The combination of aspirated and no-aspirated phonemes with yin and yang.

\begin{tabular}{|c|c|c|c|}
\hline \multicolumn{2}{|c|}{ "no-aspirated" phoneme } & \multicolumn{2}{|c|}{ “aspirated" phoneme } \\
\hline $\begin{array}{l}\text { Yin ping } \\
\text { (阴平) }\end{array}$ & $\begin{array}{c}\text { Yang ping } \\
\text { (阳平) }\end{array}$ & $\begin{array}{l}\text { Yin ping } \\
\text { (阴平) }\end{array}$ & $\begin{array}{c}\text { Yang ping } \\
\text { (阳平) }\end{array}$ \\
\hline 般[pan] & $\mathrm{O}$ & 潘[p‘an] & 盘[p‘an] \\
\hline 奔[pən] & $\mathrm{O}$ & 喷[p‘ən] & 盆[p’on] \\
\hline 边[pian] & $\mathrm{O}$ & 篇[p`ian] & 便便宜[p'ian] \\
\hline 宾[pin] & $\mathrm{O}$ & 拼[p`in] & 贫 [p'in] \\
\hline
\end{tabular}

the uneven development among dialects provide us precious "living fossil" to make research on the history of a language. Because "The language differences in space represents the various stages of language development, reflecting the time sequences of development” (Xu Tongqiang, 1991). Antoine Meillet says, it is one of the very important rule of the historical comparative method in the research of language history. Judging from the modern Chinese dialects, there are such phonetic features as devoicing and splitting in the four dialect areas among the seven. In addition, the phenomena of splitting and devoicing remain in various degrees in $\mathrm{Wu}$, Xiang and southern Min dialect areas. According to the viewpoint of the historical comparative method, such spatial differences at the synchronic plane can provide us some useful information in our research of the time sequences of splitting and the devoicing.

It is also believed that all phonetic differentiation is conditional, therefore, the time sequences can be decided judging by the conditions of differentiation. The rules are as follow: If there are conditions for the differentiation of one sound into several sounds, then the "one sound" occurred earlier than "several sounds" (In another word, it is differentiation.); if there are no conditions for "one sound" differentiating into several sounds, then "the several sounds" appeared earlier than the "one sound" (In another word, it is mergence.) (Xu Tongqiang, 1991). Thus, the idea that ping split into yin and yang in Yuan Dynasty because of the differentiation devoicing is untenable, for the conditions for differentiation at that time are suppositional and the devoicing had already finished in the Song Dynasty. We believe that the phonetic phenomenon of splitting should appear earlier than ping without yin and yang. In modern times, the development of the tones of Chinese is not so much a differentiation process as a merging process. It is also more convincing to explain the phonetic phenomenon that some Chinese dialects, which have already finished the process of devoicing, have its own ping tone. Judging from the tones of some representative dialects, such mergence is irregular, as a result, tones of Chinese dialects differ greatly.

The Chinese Phonology, written by Sweden Sinologist Klas Bernhard Johannes Karlgren, has a great impact on the study of the development of Chinese. He compares the differences between the Chinese dialects by combining the factors of space and time in order to study the development of Chinese (Xu Tongqiang, 1991). According to the modern dialect tones, Klas Bernhard Johannes Karlgren thinks, in Sui Dynasty when Qieyun 切韵 (a very important rhyming book in ancient Chinese) was written, the four tones had differentiated into "yin and yang”. Dong Tonghe 董同碖 (1965), the famous Chinese linguist, has a positive attitude to it. He thinks, “...his speculation is reasonable.” Jerry Norman (1995) thinks that, "the differences between 'yin tones' and 'yang tones' do not reflect the different phonemes but the variant pronunciation.” Of course, it is not the ultimate goal of this paper to prove the differences of the tone pitch of the allophones. What we are interested is the time of the appearance of the opposition of phonemes of "yin and yang”.

\section{Part IV}

Qieyun, written by Lu Fayan 陆法言 in Sui Dynasty (581-618), and other rhyming books based on Qieyun, along with the widely spreading poems and Chinese characters provide rich materials for the later phonological research, but the precious literature documents for the research on the develop- 
ment of Chinese tones make one feel as if returning from a treasure mountain empty-handed. First, the compilation of rhyming books serve for literary creation, and the literary language presents an obvious hysteretic nature compared with oral language. Even the modern metrical poetry is based on the Pingshuiyun 平水韵 (the rhyme system since the southern Song Dynasty), reflecting basically the rhyming patterns of the modern style poetry. For example, the poem by Mao Zedong, Qilü, Changzheng 七律·长征 “Qilü, Long March” (Qilü: eight line Chinese poem with seven charaters to a line) ryhmes on one tone: 难 nán / 闲 xián / 丸 wán / 寒 hán / 颜 yán, all on yang ping (rising tone). His another poem, “The people’s liberation army occupied Nanjing”, ryhmes on ying ping and yang ping: 黄 huáng / 江 jiāng / 慷 kāng / 王 wáng / 桑 sāng. He also uses ying ping and yang ping when composing a poem to a given tune of ci: Ascend Chingkangshan Again (Shui Diao Ge Tou: Prelude to Water Melody): 山 shān / 颜 yán / 端 duān / 看 kān / 寰 huán / 间 jiān / 还 huán / 攀 pān, etc. From these examples, we can hardly verify the differentiation and mergence of ping tone.

Second, most of the compilation style of the rhyming books after Qieyun, such as Tangyun 唐韵, Guangyun 广韵, or Jiyun 集韵, follows the rule of "considering the situations of the north and south, the ancient and the modern", so it is impossible to systemize the sound systems of one place at certain time. Third, the language materials in Fanqie 反切 (a traditional method of indicating the pronunciation of a Chinese character) are much more precise than those in rhyming books, but some problems also occur in the process of actual operation. The character needing to be indicated pronunciation should not only be based on the tone of words after it, but also restricted by the words before it whether it is voiced or voiceless. When voiced initials were not devoicing, or when the voiced initials had already devoiced in oral Chinese, but the rhyming books still follow the old system, for example, at Song Dynasty, the devoicing had already finished, the rhyming books then, such as Guangyun, Jiyun, still followed the old system: voicelesssub-voiceless-voiced-sub-voiced. Therefore, it is impossible to use the materials of Fanqie. We have to look for other literature materials in order to find the support for the time of ping split into yin and yang.

The preface and postscripts of many rhyming books give us some hints about the time of splitting. Lu Fayan, Yan Zhitui 颜 之推 (529-595) and Lu Deming 陆德明 (553?-630?) had once have incisive arguments on the Chinese tone differences. They all realized that tones differ not only in the ancient time and modern time, but also differ in the north and south of China. According to Sun Mian's 孙愐 (fl. 8th cent.) exposition in his Tangyunxu Houlun 唐韵序后论 “Postscript to Tangyunxu”, Luo Changpei 罗常培 (1956) thinks, "It has been a long time for the voiceless and voiced initials having four tones respectively."

There are descriptions on the Chinese tones in the Xiyunzang 悉是藏 “Siddham Scriptures” by Samana Enron in Dazheng Xinxiu Dazangjing 大正新修大藏经 “Taisho Tripitaka” of Japan (in Year 880). Zhou Zumo (1958) thinks, having made further research on Enron's description and some other materials, "what he 'Enron' said about the stressed and unstressed sounds is similar to yin and yang mentioned in Zhongyuan Yinyun by Zhou Deqing in the Yuan Dynasty”, so he concludes that, "In the Tang Dynasty, the four tones: ping, shang, qu, ru had already have different pronunciation due to the voiced or voiceless initials”, "In Tang Dynasty, ping had already split into two tones in most of the dialects.”

In the middle of $20^{\text {th }}$ century, many scholars made exploration to the sources of “hanyin” 汉音 and “wuyin” 吴音 in Japanese. Some of them think that, "wuyin” might come from $\mathrm{Wu}$ dialect of Chinese, some think that it borrowed from Jiangdong dialect, and others think that it came from Old Min at the lower reaches of Yangtze River. There are two sources for "hanyin": Changan dialect in Tang Dynasty and the north dialect at the late Tang Dynasty (Yan Mian, 1994). The two sources of "hanyin" are quite different from each other, but we can also make use of "hanyin". What reflects by "hanyin" can almost represent the phonetic phenomena of the north dialect of Tangy Dynasty. Thus it can be seen that ping had already split into yin and yang in the north dialect in Tang Dynasty, and as Zhou Zumo said, they belong to "two classes of tone", not merely the differences in tone pitch.

Besides the rich literature materials based on such rhyming books as Qieyun, there are some other works which are not restrained to rhyming books. Huangji Jingshi Shu. Shengyin Changhe $T u$ 皇极经世书·声音倡和图 by Shao Yong is the representative. From Min Dynasty to present, many linguists have made researches on his works and scored great achievements. Zhou Zumo (1942) made an in-depth study on it and he made clear that the basic dialect reflected in Shengyin Changhe $\mathrm{Tu}$ 声音倡和图 was Zhong Zhou dialect. Based on it, Zhou systemized the sound system of Zhong Zhou dialect in Song Dynasty.

There were ten yintu 音图 (similar to consonants list) in Shengyin Changhe Tu, and all of them were divided into voiced and voiceless, including sub-voiced “疑 $[\mathrm{y}]$, 明 $[\mathrm{m}]$, 微 [m], 泥 [n], 来[l], 日[r]”. In fact, sub-voiced initials should be voiceless. As for this phenomenon, scholars at home and abroad give different explanations (Zhou Zumo, 1942; Lu Zhiwei, 1946). Russian linguist Yakhontov (1980) gives a very good interpretation to it, based on modern Hangzhou dialect (Jiang Shaoyu, 1994).

He thinks the voiced and voiceless mentioned in Shao Yong's works refer to pitch, "the higher ones are voiceless, and the lower are voiced", so in Shao's speech, there were "seven tones: four higher ones and three lower ones." "shang are are all high pitch, and the other three belong to high or low respectively". According to his analysis, we know that there should be seven tones in the north dialect in Song Dynasty: yin ping, yang ping, shang, yin qu, yang qu, yin ru and yang ru. Li Wuwei 李 无未 (1995) thinks that "in the end of $12^{\text {th }}$ century and early $13^{\text {th }}$ century, ping had split into yin and yang”, after making research on Sun Yi's 孙奕 notes on "Ping Split into Yin and Yang”.

\section{Part V}

Some research findings indicate that the modern $\mathrm{Wu}$ dialect is similar to early modern north Chinese due to the immigration and the political center migrating south(the Southern Song Dynasty set its capital in Hangzhou for 148 years), and the modern north Chinese and early modern north Chinese are apparently parent-child relation. (In the development of society, early modern Chinese is gradually becoming modern Chinese affected by the outside world.) Therefore, modern $\mathrm{Wu}$ dialect provides us very useful materials for the study of early modern north Chinese.

As far as tones are concerned, "Wu dialect retains the four 
tones: ping, shang, qu, ru and they are grouped into yin and yang according to the voiced and voiceless initials" (Yuan Jiahua, etc. 1983). For example, in Suzhou dialect and Wenzhou dialect, "There are very strick rules for the combination between then voiced or voiceless initials and the yin or yang of the tones: voiceless initials with yin tone and voiced initials yang tone, most of the sub-voiced with yang tone, only a few exception with yin tone" (Chinese Department of Beijing University, 1989). This tone system remains connected with modern north Chinese. The evolution of Wu dialect is the historical epitome of the development of early modern north Chinese into modern north Chinese. Take Shanghai dialect as an example, since the open of the port, a lot of people rushed into Shanghai from other places of China and abroad, as a result, there are much more outsiders than the natives. In such a language environment, Shanghai dialect and the other dialects have been affected and integrated, and the sound system of Shanghai dialect has been greatly simplified. At the beginning of the opening of the port, there were eight tones in Shanghai dialect, and the Research on Contemporary Wu Dialect (Zhao Yuanren, 1956) records six or seven tones, but now only five remain (Shou Ming, 1992). Since the 1840s till now, only more than one hundred years have passed, but great changes have take place in the tones of Shanghai dialect. Considering the north Chinese, Shanghai dialect can be seen as the providing ground for the evolution of the tones of north Chinese since the Song Dynasty.

\section{Part VI}

Since the end of Tang Dynasty till now, we have reasons to believe that the tone system has been greatly simplified. During the period no later than Song Dynasty, the "Ping split into yin and yang” has the function of phoneme. We don't have enough reason to deny the fact that the editors of Qieyun had made induction in favor of literary creation. In the past poetic proses, the phenomenon that yin ping rhymes with yang ping does not reflect the fact that both the tones and their pitch change are of the similar type. Judging by the tone pitch of the modern north Chinese, the tone types of yin ping and yang ping are more similar than them to shang (falling-rising) and qu (falling), and their pitch changes are smaller than those of shang and qu. Take Chengdu dialect as an example, the pitches of its four tones are as follow: 55(45), 2l, 53, 213. Quite clear, that the differences of pitches between the first two tones are both 1 , and their differences with shang and qu are very obvious.

In the Chinese phonemes of opposites, the voiceless initials with the yin tone and the voiced initials with the yang tone are distinguishing features. Judging from the modern Xiang dialect and $\mathrm{Wu}$ dialect, Russian linguist Alexandr Dragunov thinks "If the distinction of pitch height remains, the people in Xiang dialect and $\mathrm{Wu}$ dialect areas could hardly notice the voiced initials." Thus, "what is of importance is not the opposite of the voiced and voiceless, but the distinction of the height of the tone related with it” (Quoted from Yakhontov, 1980). As a matter of course, before the devoicing, the distinction between yin and yang tone could not only be redundant features, and after the devoicing, the distinctive feature of yang tone becomes more obvious.

\section{Conclusion}

We have reasons to believe, based on the deduction of the above theories and the research findings of the ancient and modern scholars, proved by the modern dialects, it could not be in the Yuan Dynasty that ping split into yin and yang, but no later than the Song Dynasty. Whether the phonetic phenomenon can be dated back to the Tang Dynasty, up till now we haven't found sufficient proof due to the problem of "voiced initials".

\section{REFERENCES}

Chinese Department of Beijing University (1989). Chinese dialect word collection (2nd ed.) 汉语方言字汇(第二版). Beijing: Word Reformation Press.

Dong Tonghe 董同䯙 (2001). Chinese Phonology 汉语音韵学. Beijing: Zhonghua Book Company.

Hsueh (Lu Guoyao 鲁国尧, \& Shi Jianguo 侍建国, Translated) (1990). Zhongyuan Phonemic System 中原音韵音位系统. Beijing: Beijing Language College Press.

Jiang Shaoyu 蒋绍愚 (1994). Introduction to modern Chinese research 近代汉语研究概况. Beijing: Beijing University Publishing Press. 北京: 北京大学出版社.

Li Rulong 李如龙 (1991). Northern Min Dialect 闽北方言. Beijing: Chinese Publishing House. 北京: 中文出版社.

Li Wuwei 李无未 (1995). Textual research on notes on "Ping Split into Yin and Yang” by Sun Yi in Southern Song Dynasty 南宋孙奕 音注“平分阴阳”考. The Eighth Academic Conference Minutes of Association of Chinese Linguistics, Chinese Language, No. 6, Beijing.

Luo Changpei 罗常培 (1982). Introduction to Chinese historical phonology 汉语音韵学导论. Beijing: Zhonghua Book Company.

Norman, J. (Zhang Huiying 张惠英, Translated) (1995). Chinese 汉语 概说. Beijing: Language Publishing House.

San Duanmu (2007). The phonology of standard Chinese (2nd ed.). New York: Oxford University Press Inc.

Shou Ming 受鸣 (1992). Ten talks about Shanghai Dialect 上海方言 十夜谈. Shanghai: East China Normal University Press.

Wang Li 王力 (1985) Chinese historical phonology 汉语语音史. Beijing: China Social Sciences Publishing House.

Wang Wenhu 王文虎 (1994) The Phonetic Features of the Putonghua with Sichuan Accent 四川口音普通话的语音特征. Journal of Sichuan University, 3, 56-61.

Xu Tongqiang 徐通铭 (1991) Historical linguistics 历史语言学. Beijing: Commercial Press.

Yakhontov (1986). Beijing Pronunciation in the 11th Century 十一世 纪的北京音. Translated by Chen Zhongye, see Analects of History of Chinese Language, compiled by Tang Zuofan \& Hu Shuangbao. Beijing: Peking University Press.

Yang Naisi 杨耐思 (1981). Zhongyuan phonological system 中原音 韵音系. Beijing: China Social Sciences Publishing Press.

Yang Shifeng (1951). Short account of Chengdu phonetic system 成都 音系记略. Vol. 1, 23rd Collections. Taipei: The Institute of History and Philology.

Yuan Jiahua 袁家骅, et al. (1983). Outline of Chinese Dialect (2nd ed.) 汉语方言概要(第二版). Beijing: Language Reform Press.

Zhao Yuanren 赵元任 (1956) Research on modern Wu Dialect 现代 吴语的研究. Beijing: Science Press.

Zhen Shanglin 甄尚灵 (1988) West Sichuan Dialect and Chengdu Dialect 《西蜀方言》与成都语音. Dialects, 3, 209-219.

Zhou Zumo 周祖谟 (1966) Textual research on Bianluo Sounds in Song Dynasty 宋代泣洛语音考. In Collections of Seeking Knowledge (pp. 581-655). Beijing: Zhonghua Book Company.

Zhou Zumo 周祖谟 (1958) Some materials about the pronunciation of the four tones in Tang Dialect 关于唐代方言中四声读法之一些资 料. In Collections of Seeking Knowledge (pp. 494-500). Beijing: Zhonghua Book Company. 